\title{
REVIEW OF ECOTOXICOLOGICAL STUDIES OF THE MARINE AND ESTUARINE ENVIRONMENTS OF THE BAIXADA SANTISTA (SÃO PAULO, BRAZIL)
}

\author{
Eduinetty Ceci Pereira Moreira de Sousa ${ }^{l}$, Letícia Pires Zaroni ${ }^{l}$, \\ Marcia Regina Gasparro ${ }^{l, *}$ and Camilo Dias Seabra Pereira ${ }^{2}$ \\ ${ }^{1}$ Instituto Oceanográfico da Universidade de São Paulo \\ (Praça do Oceanográfico, 191, 05508-120 São Paulo, SP, Brasil) \\ ${ }^{2}$ Universidade Santa Cecília \\ (Rua Oswaldo Cruz, 277, 11045-907 Santos, SP, Brasil) \\ *Corresponding author: gasper@usp.br
}

http://dx.doi.org/10.1590/S1679-87592014063006202

\section{A B S T R A C T}

The aim of the present study was to identify, through ecotoxicological assays, the most critical areas in the Baixada Santista area by compiling scientific papers and technical reports of the state environmental agency. Sediment samples were assessed employing Tiburonella viscana, Leptocheirus plumulosus, Nitokra sp., and embryos of Lytechinus variegatus and Perna perna. Water column samples were assessed by using Vibrio fischeri and Lytechinus variegatus. A total of 217 samples were compiled. It was found that the frequency of acute toxicity was higher in integral sediment samples from the Santos Channel (70.68\%) and the lowest frequency was obtained for Bertioga beach samples (15\%). Sediment from the Santos and São Vicente Channels, Santos Bay and the area for the disposal of dredged material are the places most affected, whereas the beaches of Guarujá and Bertioga presented low levels of toxicity. No ecotoxicological studies were found in Mongaguá, Itanhaém or Peruíbe cities.

\section{RESUMO}

O objetivo deste trabalho foi identificar, através de ensaios ecotoxicológicos com amostras ambientais, as áreas mais críticas na Baixada Santista compilando trabalhos científicos e relatórios técnicos do órgão ambiental estadual. Para o sedimento foram utilizadas espécies como Tiburonella viscana e Leptocheirus plumulosus, Nitokra sp, embriões de Lytechinus variegatus e de Perna perna. Para a coluna de água foram realizados ensaios com Vibrio fischeri e Lytechinus variegatus. No total foram compiladas 217 amostras. Verificou-se que a frequência de toxicidade aguda foi maior nas amostras de sedimento integral do Canal de Santos (70,68\%), e a menor frequência foi obtida para as praias de Bertioga (15\%). O sedimento do Canal de Santos, Canal de São Vicente e Baía de Santos e da área de descarte do material dragado foram as regiões mais afetadas, enquanto que as Praias de Bertioga e Guarujá foram as de menor frequência de toxicidade. Não foram identificados estudos para os municípios de Mongaguá, Itanhaém e Peruíbe.

Descriptors: Toxicity tests, Baixada Santista, Amphipods, Copepods, Sea urchin and mussel embryos, Bacteria.

Descritores: Ensaios ecotoxicológicos, Baixada santista, Anfípodos, copépodos, Embriões de ouriçodo-mar e mexilhão, Bactéria.

\section{INTRODUCTION}

Over the course of the history of humanity, coastlines have been the areas most sought for human settlement. Currently approximately $60 \%$ of the world's population lives in coastal areas (LINDEBOOM, 2002). Social and economic developments have affected marine environments, resulting in changes in biogeochemical cycles, in the capacity for the production of biomass, loss of diversity, among other problems (NEVES et al., 2008).
The Baixada Santista (an area of $2,422 \mathrm{~km}^{2}$ extending from $24^{\circ} 24^{\prime} 20^{\prime \prime} \mathrm{S} 47^{\circ} 00^{\prime} 18^{\prime \prime} \mathrm{W}$ to 2345'30'S 45'52'14' W) covers nine coastal municipalities: Bertioga, Guarujá, Santos, São Vicente, Cubatão, Praia Grande, Mongaguá, Itanhaém and Peruíbe. This area had a population of 1.7 million in 2010, which could double during summer. The Baixada Santista also has one of the largest mangrove areas in the São Paulo state, with a vast stretch of sand bar.

The environmental sanitation agency of the São Paulo State (CETESB - Companhia de Tecnologia de Saneamento Ambiental) has been conducting 
studies in the Santos/São Vicente Bay and estuary since 1970. These studies have found that this is one of the most eutrophic regions in the world, with high primary production rates, high availability of nutrients and contamination by fecal coliforms in areas near the beaches and estuary, as well as contamination by metals $(\mathrm{Hg}$ and $\mathrm{Pb})$ (CETESB, 2004).

In the 1980s, CETESB carried out a new study of the area, including in its scope water, air, soil and vegetation, and its results indicated that the entire bay and estuary were in a critical condition due to the unusually high levels of metals.

A study on the quality of the water initiated in the late 1990s indicated a considerable decrease of some contaminants, although $\mathrm{Hg}$, halogenated aromatic compounds, and pesticides were found in sediment and organisms. The toxicity tests had not thus far been employed.

Over the last two decades, urban and port development has caused a considerable increase in the discharge of pollutants, and currently some of the cities in the Baixada Santista monitor the quality of their coastal waters, especially their suitability for bathing. Some of them, such as Praia Grande, Guarujá and Santos, have submarine sewage outfalls which have brought considerable improvement to water quality.

The submarine outfalls improve the water quality at the beaches, but they are a source of pollutants such as surfactants, pharmaceuticals, metals, organic material, and other compounds to the bay. The precipitation of solids around the diffusers area may result in toxicity as well as alteration in the composition of the benthic fauna (ABESSA et al., 2005; BORGES et al., 2008; CORTEZ, 2010).

The levels of xenobiotics can be measured in sediment and water column, but their biological effects cannot be assessed by chemical analysis, so ecotoxicological assays are helpful for assessing pollutant bioavailability and its effects in the aquatic environment (POWER \& CHAPMAN, 1995). Ecotoxicological assays are procedures employed as a tool for the assessment of the harmful effects of single chemical substances, complex mixtures and environmental samples on previously selected organisms (RAND et al., 1995).

The application of ecotoxicological assays to assess the toxicity of effluents and environmental samples began in Brazil in the late 1980s. One of the first applications of toxicity tests to environmental samples of water and sediment from the Santos region was carried out by RACHID (1996) around the Santos submarine sewage outfall, and another by ABESSA (1996) in sediment from the Santos/São Vicente Bay and estuary.

This study presents a broad review of the ecotoxicological assessments performed in the
Baixada Santista region, as well as identifying critical areas that should be subjected to monitoring, remediation and further studies.

\section{Material and Methods}

This review includes only scientific studies undertaken by universities and research institutes, and technical reports from CETESB, obtained between 1996 and 2011. It does not include data from studies carried out for the purpose of applying for licenses and environmental monitoring for installation and operation of industrial or port activities.

The Baixada Santista region was divided into nine large areas according to their uses and types of anthropic interference (Fig. 1), as follows: Bertioga beaches, Bertioga Channel, Santos Channel - port, São Vicente Channel, Santos Bay, Guarujá, dredge material disposal area, Laje de Santos and Praia Grande - outfalls. Ecotoxicological studies with samples from the cities of Mongaguá, Itanhaém and Peruíbe were not found. The locations where ecotoxicologic test samples were collected, both for sediment and for water column assays, were plotted in their respective areas, as illustrated in Figure 1. When multiple samples were obtained from any given sites, they have been assigned only one identification regardless of specific sample area.

The number of samples obtained was multiplied by the number of tests applied to each sample. The study includes the total number and types of tests performed in many different sections of the study in each region, as well as number of samples that had an acute and/or chronic effect, in each study (Table 1 and Table 2).

All the studies compiled employed ecotoxicological assays to assess environment samples through widely used methods, such as those proposed by MELO (1993) and MELO \& NIPPER (2007) for testing acute effects in whole sediment samples with the marine amphipod Tiburonella viscana. For this burrowing amphipod and for the estuarine amphipod Leptocheirus plumulosus the assays were performed in accordance with ABNT NBR (2008). The chronic effect assay with whole sediment and interstitial water with the harpacticoid copepod Nitokra sp were performed in accordance with LOTUFO \& ABESSA (2002). The short duration chronic assay with Lytechinus variegatus embryos was initially described by USEPA (1988), CETESB (1992) and later regulated by ABNT NBR (2006), as well as the acute effect assay with $L$. variegatus gametes. Moreover, chronic effect assays were also performed with bivalve embryos as recommended by ASTM (1992) and adapted for Perna perna mussel by ZARONI et al. (2005). The acute effect assay with the marine bacteria Vibrio fischeri was performed in accordance with ABNT NBR (2007). 


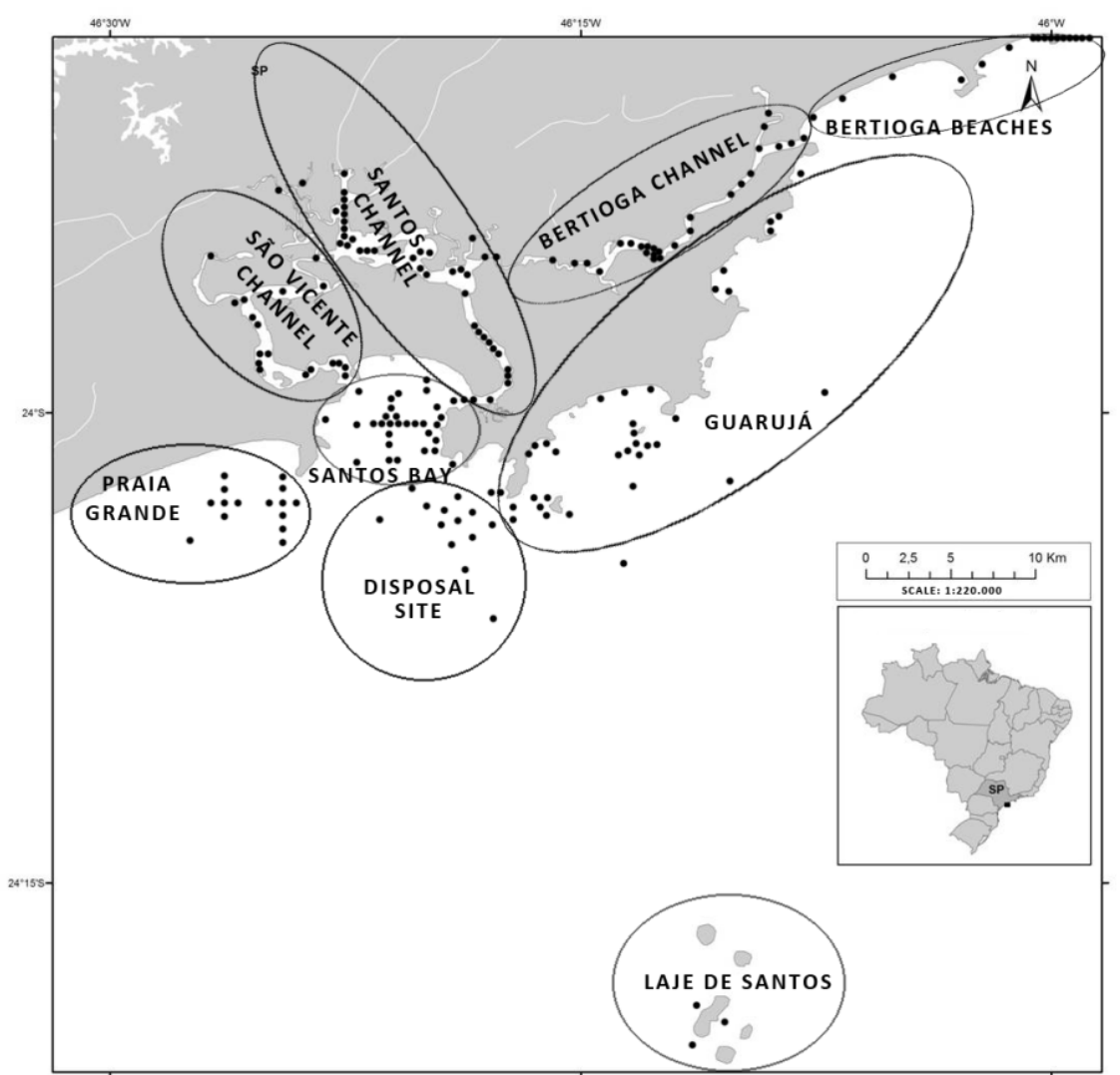

Fig. 1. Stations for ecotoxicological tests (small dots) and 9 areas locations (circles) defined according to the use and types of anthropogenic interference from Baixada Santista.

Table 1. Summary of studies, sample sites and samples related to each area.

\begin{tabular}{lcccc}
\hline \hline \multicolumn{1}{c}{ Area } & $\begin{array}{c}\text { Studies } \\
\text { Number }\end{array}$ & $\begin{array}{c}\text { Total Sample } \\
\text { Sites }\end{array}$ & $\begin{array}{c}\text { Sediment Sample } \\
\text { Number }\end{array}$ & $\begin{array}{c}\text { Water Sample } \\
\text { Number }\end{array}$ \\
\hline Santos Bay & 11 & 32 & 51 & 74 \\
Santos Channel & 14 & 51 & 64 & 10 \\
São Vicente Channel & 7 & 19 & 26 & 6 \\
Channel and Beaches & 5 & 45 & 87 & 19 \\
Bertioga & & & & 0 \\
Dredge Material Disposal & 4 & 16 & 21 & 15 \\
Praia Grande & 2 & 36 & 15 & 15 \\
Guarujá & 7 & 3 & 0 & 3 \\
Laje de Santos & 1 & 217 & 306 & 142 \\
Total & 51 & & & \\
\hline
\end{tabular}


Table 2. Summary of studies in Baixada Santista by area, type of effect, number of sampling campaigns for sites, test organism used in each fraction, number of toxic samples per number of samples analyzed and reference.

\begin{tabular}{|c|c|c|c|c|c|}
\hline Area & Assay & $\begin{array}{l}\text { Sampling } \\
\text { Campaigns/Sites }\end{array}$ & Fraction / Organisms & $\begin{array}{c}\text { Toxic Samples/ } \\
\text { Samples Analyzed }\end{array}$ & Reference \\
\hline \multirow[t]{20}{*}{ Santos Bay } & Chronic & $2 / 1$ & Column - L. variegatus & $1 / 2$ & Rachid, 1996 \\
\hline & \multirow[t]{3}{*}{ Acute } & $2 / 2$ and $1 / 1$ & Sediment - $T$. viscana & $3 / 5$ & Abessa, 1996 \\
\hline & & $1 / 5$ & Sediment - T. viscana & $3 / 5$ & Abessa \& Sousa, 2001 \\
\hline & & $1 / 9$ & Sediment - T. vicana & $2 / 9$ & Abessa et al., 2008 \\
\hline & Chronic & & Interstitial - L. variegatus & $9 / 9$ & \\
\hline & \multirow[t]{4}{*}{ Chronic } & $12 / 3$ & Column - surface - L. variegatus & $1 / 36$ & Pereira et al., 2004 \\
\hline & & & Column - bottom - L. variegatus & $15 / 36$ & \\
\hline & & $1 / 4$ & Interstitial - L. variegatus & $4 / 4$ & Prósperi, 2002 \\
\hline & & & Interface - $L$. variegatus & $2 / 4$ & \\
\hline & \multirow[t]{2}{*}{ Acute } & $5 / 5$ & Sediment $-T$. viscana & $12 / 25$ & Abessa et al., 2005 \\
\hline & & $1 / 1$ & Sediment - T. viscana & $1 / 1$ & Cesar et al., 2006; \\
\hline & \multirow[t]{2}{*}{ Chronic } & & Interstitial - L. variegatus & $1 / 1$ & Pusceddu et al., 2007 \\
\hline & & & Interface $-L$. variegatus & $1 / 1$ & \\
\hline & Acute & $1 / 1$ & Sediment $-T$. viscana & $1 / 1$ & Torres et al., 2009 \\
\hline & \multirow{2}{*}{ Chronic } & & Interstitial - L. variegatus & $1 / 1$ & \\
\hline & & & Elutriate - L. variegatus & $1 / 1$ & \\
\hline & Acute & $1 / 1$ & Sediment - T. viscana & $0 / 1$ & Moreira, 2009 \\
\hline & \multirow{3}{*}{ Chronic } & & Interstitial - L. variegatus & $1 / 1$ & \\
\hline & & & Elutriate - L. variegatus & $0 / 1$ & \\
\hline & & & Interface - L. variegatus & $1 / 1$ & \\
\hline \multirow[t]{33}{*}{ Santos Channel } & \multirow[t]{2}{*}{ Acute } & $3 / 2$ & Sediment - T viscana & $5 / 6$ & Abessa, 1996 \\
\hline & & $1 / 8$ & Sediment - $T$ viscana & $8 / 8$ & Abessa et al., 2008 \\
\hline & \multirow[t]{3}{*}{ Chronic } & & Interstitial - $L$ variegatus & $8 / 8$ & \\
\hline & & $1 / 12$ & Interstitial - $L$ variegatus & $9 / 12$ & Prósperi, 2002 \\
\hline & & & Interface - L variegatus & $6 / 12$ & \\
\hline & Acute & $2 / 1$ & Sediment - $T$ viscana & $1 / 2$ & Argentino-Santos, 2006 \\
\hline & \multirow[t]{3}{*}{ Chronic } & & Interstitial - $L$ variegatus & $2 / 2$ & \\
\hline & & & Interface - $L$ variegatus & $2 / 2$ & \\
\hline & & & Sediment - Nitokra sp & $1 / 2$ & \\
\hline & Acute & $1 / 3$ and $2 / 3$ & Sediment - L plumulosus & $1 / 3$ & CETESB, 2006 \\
\hline & Chronic & & Interface - $L$ variegatus & $3 / 6$ & \\
\hline & Acute & $1 / 3$ & Sediment - $T$ viscana & $2 / 3$ & Cesar et al., 2006; \\
\hline & \multirow[t]{2}{*}{ Chronic } & & Interstitial - $L$ variegatus & $3 / 3$ & Pusceddu et al., 2007 \\
\hline & & & Interface - $L$ variegatus & $2 / 3$ & \\
\hline & Acute & $2 / 3$ & Sediment - L plumulosus & $0 / 6$ & CETESB, 2007 \\
\hline & Chronic & & Interface - $L$ variegatus & $4 / 6$ & \\
\hline & Acute & $1 / 6$ & Sediment - $T$ viscana & $6 / 6$ & Sousa et al., 2007 \\
\hline & Chronic & & Elutriate - L variegatus & $4 / 6$ & \\
\hline & Acute & $2 / 5$ & Sediment - $T$ viscana & $3 / 10$ & Sousa et al., 2008; \\
\hline & \multirow[t]{6}{*}{ Chronic } & & Elutriate - L variegatus & $7 / 10$ & Gianesella et al., 2008 \\
\hline & & & Interstitial - $L$ variegatus & $8 / 10$ & \\
\hline & & & Interface - $L$ variegatus & $5 / 10$ & \\
\hline & & & Sediment - Nitokra $\mathrm{sp}$ & $2 / 10$ & \\
\hline & & & Interstitial - Nitokra sp & $1 / 10$ & \\
\hline & & & Column - L variegatus & $3 / 10$ & \\
\hline & \multirow[t]{2}{*}{ Acute } & & Column - V fischeri & $0 / 10$ & \\
\hline & & $1 / 4$ & Sediment - $T$ viscana & $0 / 4$ & Torres et al., 2009 \\
\hline & \multirow[t]{2}{*}{ Chronic } & & Interstitial - $L$ variegatus & $4 / 4$ & \\
\hline & & & Elutriate - L variegatus & $2 / 4$ & \\
\hline & Acute & $1 / 4$ & Sediment - $T$ viscana & $1 / 4$ & Moreira, 2009 \\
\hline & Chronic & & Interstitial - L variegatus & $4 / 4$ & \\
\hline & & & Elutriate - L variegatus & $4 / 4$ & \\
\hline & & & Interface - $L$ variegatus & $4 / 4$ & \\
\hline São Vicente & Acute & $3 / 2$ & Sediment - T. viscana & $5 / 6$ & Abessa, 1996 \\
\hline Channel & & $1 / 5$ & Sediment - T. viscana & $2 / 5$ & Abessa et al., 2008 \\
\hline & Chronic & & Interstitial - L. variegatus & $5 / 5$ & \\
\hline & & $1 / 7$ & Interstitial - L. variegatus & $6 / 7$ & Prósperi, 2002 \\
\hline & & & Interface - $L$. variegatus & $1 / 7$ & \\
\hline & Acute & $1 / 2$ & Sediment - $T$. viscana & $1 / 2$ & Cesar et al., 2006; \\
\hline & Chronic & & Interstitial - L. variegatus & $2 / 2$ & Pusceddu et al., 2007 \\
\hline & & & Interface - L. variegatus & $2 / 2$ & \\
\hline
\end{tabular}


Table 2. Continuation.

\begin{tabular}{|c|c|c|c|c|c|}
\hline Area & Assay & $\begin{array}{l}\text { Sampling } \\
\text { Campaigns/Sites }\end{array}$ & Fraction / Organisms & $\begin{array}{c}\text { Toxic Samples/ } \\
\text { Samples Analyzed }\end{array}$ & Reference \\
\hline São Vicente & Acute & $2 / 3$ & Sediment - T. viscana & $1 / 6$ & Sousa et al., 2008, \\
\hline \multirow[t]{7}{*}{ Channel } & Chronic & & Sediment - Nitokra sp & $1 / 6$ & Gianesella et al., 2008 \\
\hline & & & Interface - L. variegatus & $5 / 6$ & \\
\hline & & & Elutriate $-L$. variegatus & $3 / 6$ & \\
\hline & & & Interstitial - L. variegatus & $5 / 6$ & \\
\hline & & & Interstitial - Nitokra sp & $0 / 6$ & \\
\hline & & & Column - L. variegatus & $1 / 6$ & \\
\hline & Acute & & Column - V. fischeri & $0 / 6$ & \\
\hline Bertioga & Acute & $1 / 2$ & Sediment - T viscana & $2 / 2$ & Abessa et al., 2008 \\
\hline \multirow[t]{13}{*}{ Channel } & Chronic & & Interstitial - $L$ variegatus & $1 / 1$ & \\
\hline & Acute & $2 / 7$ and $2 / 6$ & Sediment $-T$. viscana & $1 / 12$ & Zaroni, 2006 \\
\hline & Chronic & & Sediment - Nitokra sp & $3 / 19$ & \\
\hline & Acute & & Acute Interstitial - L. variegatus & $4 / 12$ & \\
\hline & Chronic & & Interstitial - L. variegatus & $17 / 26$ & \\
\hline & & & Interstitial - Nitokra sp & $3 / 12$ & \\
\hline & & & Interstitial $-P$. perna & $10 / 13$ & \\
\hline & Chronic & $1 / 1$ & Interstitial - L. variegatus & $1 / 1$ & Pusceddu et al., 2007 \\
\hline & & & Interface - L. variegatus & $1 / 1$ & \\
\hline & Acute & $1 / 5$ and $1 / 4$ & Sediment - L. plumulosus & $0 / 5$ & CETESB, 2008 \\
\hline & Chronic & & Interface - L. variegatus & $1 / 5$ & \\
\hline & Acute & & Column - V. fischeri & $0 / 4$ & \\
\hline & & $1 / 11$ & Sediment - T. viscana & $10 / 11$ & Pozo et al., 2011 \\
\hline Bertioga & Acute & $1 / 15$ and $2 / 5$ & Sediment $-T$. viscana & $0 / 10$ & Zaroni, 2006 \\
\hline \multirow[t]{5}{*}{ Beaches } & & & Sediment - Nitokra sp & $1 / 10$ & \\
\hline & & & Acute Interstitial - L. variegatus & $3 / 10$ & \\
\hline & Chronic & & Interstitial - L. variegatus & $8 / 20$ & \\
\hline & & & Interstitial - Nitokra sp & $1 / 10$ & \\
\hline & & & Interstitial - P. perna & $14 / 20$ & \\
\hline Dredge & Chronic & $1 / 2$ & Interstitial - L. variegatus & $2 / 2$ & Prósperi, 2002 \\
\hline Material & & & Interface - L. variegatus & $1 / 2$ & \\
\hline \multirow[t]{9}{*}{ Disposal } & Acute & $2 / 5$ & Sediment - T. viscana & $4 / 10$ & Argentino-Santos, 2006 \\
\hline & Chronic & & Interstitial - L. variegatus & $10 / 10$ & \\
\hline & & & Interface - L. variegatus & $0 / 10$ & \\
\hline & & & Sediment - Nitokra sp & $1 / 10$ & \\
\hline & Acute & $1 / 4$ & Sediment $-T$. viscana & $2 / 4$ & Sousa et al., 2007 \\
\hline & Chronic & & Elutriate - L. variegatus & $0 / 4$ & \\
\hline & Acute & $1 / 5$ & Sediment - T. viscana & $0 / 5$ & Torres et al., 2009 \\
\hline & Chronic & & Elutriate - L. variegatus & $5 / 5$ & \\
\hline & & & Interstitial - L. variegatus & $2 / 5$ & \\
\hline \multirow[t]{4}{*}{ Praia Grande } & Acute & $1 / 10$ & Sediment - T. viscana & $6 / 10$ & Abessa \& Sousa, 2001 \\
\hline & & $1 / 5$ & Sediment - L. plumulosus & $1 / 5$ & CETESB, 2008 \\
\hline & Chronic & & Interface - L. variegatu & $0 / 5$ & \\
\hline & Acute & & Column - V. fischeri & $0 / 5$ & \\
\hline \multirow[t]{18}{*}{ Guarujá } & Acute & $1 / 7$ & Sediment - T. viscana & $4 / 7$ & Abessa \& Sousa, 2001 \\
\hline & & $1 / 1$ & Sediment - T. viscana & $0 / 1$ & Abessa et al., 2008 \\
\hline & Chronic & & Interstitial - L. variegatus & $1 / 1$ & \\
\hline & Acute & $2 / 6$ & Sediment - T. viscana & $3 / 12$ & Argentino-Santos, 2006 \\
\hline & Chronic & & Sediment - Nitokra sp & $1 / 12$ & \\
\hline & & & Interstitial - L. variegatus & $4 / 12$ & \\
\hline & & & Interface - L. variegatus & $0 / 12$ & \\
\hline & Acute & $1 / 3$ & Sediment $-T$. viscana & $2 / 3$ & Sousa et al., 2007 \\
\hline & Chronic & & Elutriate - L. variegatus & $0 / 3$ & \\
\hline & Acute & $1 / 3$ & Sediment - L. plumulosus & $0 / 3$ & CETESB, 2008 \\
\hline & Chronic & & Interface - L. variegatus & $2 / 3$ & \\
\hline & Acute & & Column - V. fischeri & $0 / 3$ & \\
\hline & Chronic & $1 / 12$ & Interface - L. variegatus & $6 / 12$ & Medeiros et al., 2009 \\
\hline & & & Elutriate - L. variegatus & $1 / 12$ & \\
\hline & & & Column - L. variegatus & $5 / 12$ & \\
\hline & Acute & $1 / 4$ & Sediment - T. viscana & $1 / 4$ & Torres et al., 2009 \\
\hline & Chronic & & Elutriate - L. variegatus & $3 / 4$ & \\
\hline & & & Interstitial - L. variegatus & $3 / 4$ & \\
\hline Laje de Santos & Chronic & $1 / 3$ & Column - L. variegatus & $1 / 3$ & Abessa et al., 2004 \\
\hline
\end{tabular}




\section{Results AND Discussion}

The number of samples obtained in the estuaries, beaches and internal platform covered 217 sampling sites of the Baixada Santista. A summary of the studies, sampling sites, effects and organisms are shown in Tables 1 and 2.

Initial toxicity assessment studies of water column and sediment were performed in 1996 by RACHID (1996) and ABESSA (1996). RACHID (1996) assessed urban effluent samples from Praia Grande, Santos/São Vicente, Guarujá and São Sebastião using acute and chronic assays with $L$. variegatus gametes and embryos. Water column samples obtained near the diffusers of the submarine outfall of Santos Bay were also assessed. ABESSA (1996), however, attempted to measure sediment toxicity on the Tiburonella viscana burrowing amphipod, by collecting samples in the Santos region previously known to be contaminated (Santos and São Vicente Channels, Santos Bay, outfall discharge zone).

Early in 1999, CETESB undertook a study on the contamination of the Baixada Santista coastal environment with 26 sampling sites, including rivers, estuaries, beaches and the inner platform. Water, sediment and organism were obtained and subjected to microbiological, physical and chemical assays (LAMPARELLI et al., 2001). Indeed, chronic ecotoxicological assays with sea urchin embryos, carried out by PRÓSPERI (2002) in 18 marine and estuarine sediment samples were intended to compare methodologies for assessing sediment/water interface and interstitial water and find out what methods was most suitable for diagnosing toxic effects in such matrixes.

ABESSA (2002) and ABESSA et al. (2008) evaluated the sediment quality of 25 sampling sites in the Santos bay and estuary using the Triad Sediment Quality approach. That same study also included a temporal toxicity assessment of sediments collected near the Santos submarine outfall discharges.

Other studies carried out by ZARONI (2006), ARGENTINO-SANTOS (2006), CATHARINO et al. (2008) and TORRES et al. (2009) indicated critical zones due to toxicity and/or the presence of xenobiotics.

In Bertioga, the quality of marine and estuarine sediments (Bertioga Channel; beaches; Itapanhaú, Itaguaré and Guaratuba rivers) was thoroughly evaluated by ZARONI (2006) by the Triad Sediment Quality approach. One of the lines of evidence was the ecotoxicological assays performed on sediment (whole sediment and interstitial water) with $T$. viscana, Nitokra sp., L. variegatus and $P$. perna. In addition, the same study assessed the structure of the benthic community and undertook physical and chemical analysis of sediment samples obtained from 22 sampling sites.

In Brazil, after the Brazilian Legislation for Dredged Sediments (CONAMA n³44; BRAZIL, 2004), studies including ecotoxicological assays and chemical analysis of sediments to be dredged and their disposal area became a requirement for the classification and management of dredged material.

ARGENTINO-SANTOS (2006) assessed 12 sampling sites in four different areas in the Baixada Santista region: Santos Channel, Santos Bay, former and current disposal areas, and around the dispersion area of dredged material off the Guarujá coast. This study evaluated sediment toxicity in the dredged material disposal area, in the Santos channel port, and in the coastal dispersion area for dredged sediment. Ecotoxicological assays were performed with the liquid and solid fractions of the sediment before and after dredging activity, using $L$. variegatus embryos, T. viscana and Nitokra sp as test organisms.

With the same purpose of assessing the impact of dredging activities in the Santos Channel, TORRES et al. (2009) increased the number of samples to cover 14 sites, distributed from the Santos Channel to the dredged material disposal and dispersion areas, and used T. viscana as test organism for the whole sediment and $L$. variegatus embryos for interstitial water and elutriate assays.

During two consecutive years, CETESB (2006 and 2007) monitored the condition of the Santos Channel in the following places: near the Conceiçãozinha slums (Guarujá), near the port of Santos (Macuco district) and between the liquid bulk terminal and Bagres island, performing acute and chronic tests with sediment and interface sediment water employing Leptocheirus plumulosus and sea urchin embryos, respectively.

CESAR et al. (2006) assessed six sediment samples from the estuary and port of Santos performing acute assays with whole sediment, while PUSCEDDU et al. (2007), using the same samples, evaluated the chronic toxicity of interstitial water and sediment/water interface.

SOUSA et al. (2007) evaluated sediment quality in the Santos Channel using acute ecotoxicological assays with $T$. viscana in six samples of whole sediment obtained from the Piaçaguera Channel as far as Ponta da Praia, and seven samples from the dredged material disposal area by means of chronic effect test with sea urchin embryos and elutriate, as well as the presence of contaminants in this area.

MOREIRA (2009) performed tests with whole sediment and Tiburonella viscana; interstitial water, sediment/water interface and elutriate with $L$. variegatus embryos to assess sediment quality in three 
port areas on the Brazilian coast, including the Santos Channel.

Due to the significant increase in pollutants resulting from the submarine outfall and/or from in natura household effluents that occurs during the summer holiday season and as the contaminants accumulate in the sediment in amounts well above the levels found in the water column, ABESSA \& SOUSA (2001) used sediment samples and the T. viscana amphipod as test subjects to measure the effect of urban sewage effluent discharged by the submarine outfall around the diffusers of the four outfalls in the Baixada Santista region: one off Guarujá (Enseada Beach), one off Santos (Santos Bay) and two off Praia Grande (subsystems 1 and 2) (Table 2). ABESSA et al. (2005) also monitored the concentration level of contaminants and sediment toxicity collected during five campaigns around their diffusers of the submarine outfall off Santos.

Other studies were performed in the Santos and São Vicente estuaries, using chronic and acute tests for assessing water column and sediment (whole sediment, interstitial water and sediment/water interface) samples from eight collecting sites in winter and summer (GIANESELLA et al., 2008; SOUSA et al., 2008).

In 2008, CETESB evaluated the toxicity levels of three sediment samples from the area near the outfall diffusers off Guarujá (Enseada beach) through whole sediment tests with $L$. plumulosus and sediment/water interface with $L$. variegatus embryos. In Praia Grande, CETESB (2008) performed acute assays with $V$. fischeri in water column samples, beside acute tests with L. plumulosus in the sediment and chronic tests with L. variegatus embryos in the sediment/water interface of five samples obtained around the two submarine outfalls, three in subsystem 1 and two in subsystem 2 .

Other studies have been performed in more restricted areas. PEREIRA et al. (2004) used ecotoxicological assays with embryo-larval development of $L$. variegatus aiming to evaluate the quality of surface and bottom sea water around Ilha das Palmas, Santos Bay. Water quality around Laje de Santos has only been studied by ABESSA et al. (2004) using this same test in three samples from the water column.

In 2008, CETESB extended the monitoring network along the Bertioga Channel and evaluated the acute effect of four water samples for $V$. fischeri bacteria, five sediment samples for the L. plumulosus amphipod and the chronic effect for the sediment/water interface with $L$. variegatus embryos.

In Guarujá, MEDEIROS et al. (2009), aiming to evaluate environment quality at the Tombo, Enseada, Perequê and Iporanga beaches, collected both water and sediment samples to perform chronic assays with sea urchin embryos in the water column, elutriate and sediment/water interface.

More recently, POZO et al. (2011) performed a single study of 11 samples from the Bertioga Channel, using acute assay with $T$. viscana to evaluate the sediment toxicity of an area under the influence of marinas.

The ecotoxicological assays discussed above have shown that there are differences between areas as regards the number of studies, as well as higher frequency of acute and/or chronic effects. These results are shown in the graphs of Figure 2 (tests performed on water column samples), Figure 3 (tests made on sediment samples), and Figure 4 (the total of tests performed both in the water column and sediment, and their multiple fractions).

Water column samples were evaluated for chronic effect and $L$. variegatus embryo tests, and acute effect tests with the V. fischeri bacteria. It is verifiable that the chronic effect tests with $L$. variegatus sea urchin embryos indicate low toxicity frequency, associated both with the influence of diffuse sources and urban sewage outfalls (RACHID, 1996; MEDEIROS et al., 2009; SOUSA et al., 2008), while the acute effect tests did not indicate toxicity in any of the test samples.

The water column samples collected off Guarujá did not show acute toxicity (CETESB 2008), while chronic assays found low toxicity in all areas, except the Tombo, Enseada and Perequê beaches in Guarujá (MEDEIROS et al., 2009). As reported by CETESB (2008), the water samples around the submarine sewage outfalls showed levels of chrome, nickel, dissolved copper and iron above the limit proposed by CONAMA 357/2005.

Tests with the $V$. fischeri bacteria are widely used in bench tests and are very effective in assessing the toxicity of industrial, sector-based effluents, in assessing treatment plant efficiency and even single chemical compounds, but their application is controversial in environmental samples, especially from the water column, where the contamination level is lower. According to ROSEN et al. (2005), other types of test, such as chronic assays of bivalves and echinoderms (embryo-larval development) employed in assessing water column samples from the San Diego Bay in California have been considered more efficient.

There is a consensus that sediments concentrate toxic and persistent chemical compounds in much higher levels than the water column. This is a fact that must be taken into account in the study of coastline ecosystems affected by multiple sources of contamination (CHAPMAN, 1990 and GEFFARD $e t$ al, 2003). Contaminants, whether organic or not, affect, to a greater or lesser degree, the environmental quality of aquatic ecosystems as a result of their origin 
and the location of the polluting source(s), the flow and level of pollutants, input form and hydrodynamic, chemical and ecotoxicological characteristics and behavior and persistence in the water, in sediments and in the food chain (LAMPARELLI et al., 2001). That is why a significant number of studies have been carried out on the sediment and its fractions, as shown in Figure 3.

In spite of differences among the studies, such as those relating to areas and goals, the tests have been performed with both liquid samples and sediment basically employing the same species.

In the acute assays applied to whole sediment samples, T. viscana has been the most used, and $L$. plumulosus the most recent. Although less frequently, the Nitokra sp. Copepod has also been used in whole sediment and interstitial water chronic assays. L. variegatus embryos have been widely used for assessing the acute and chronic effects of water column, interstitial water, elutriate and sediment/water interface.

In this review, a greater frequency of acute toxicity was found in whole sediment samples from the Santos Channel (52\%), followed by São Vicente Channel, Santos Bay and Praia Grande, with $47 \%$ in each area, while sediment from the beaches of Bertioga showed a lower frequency of acute effect $(15 \%)$. Among the organisms used in the whole sediment tests, $T$. viscana was more sensitive than $L$. Plumulosus, with $56.9 \%$ of the total toxicity.

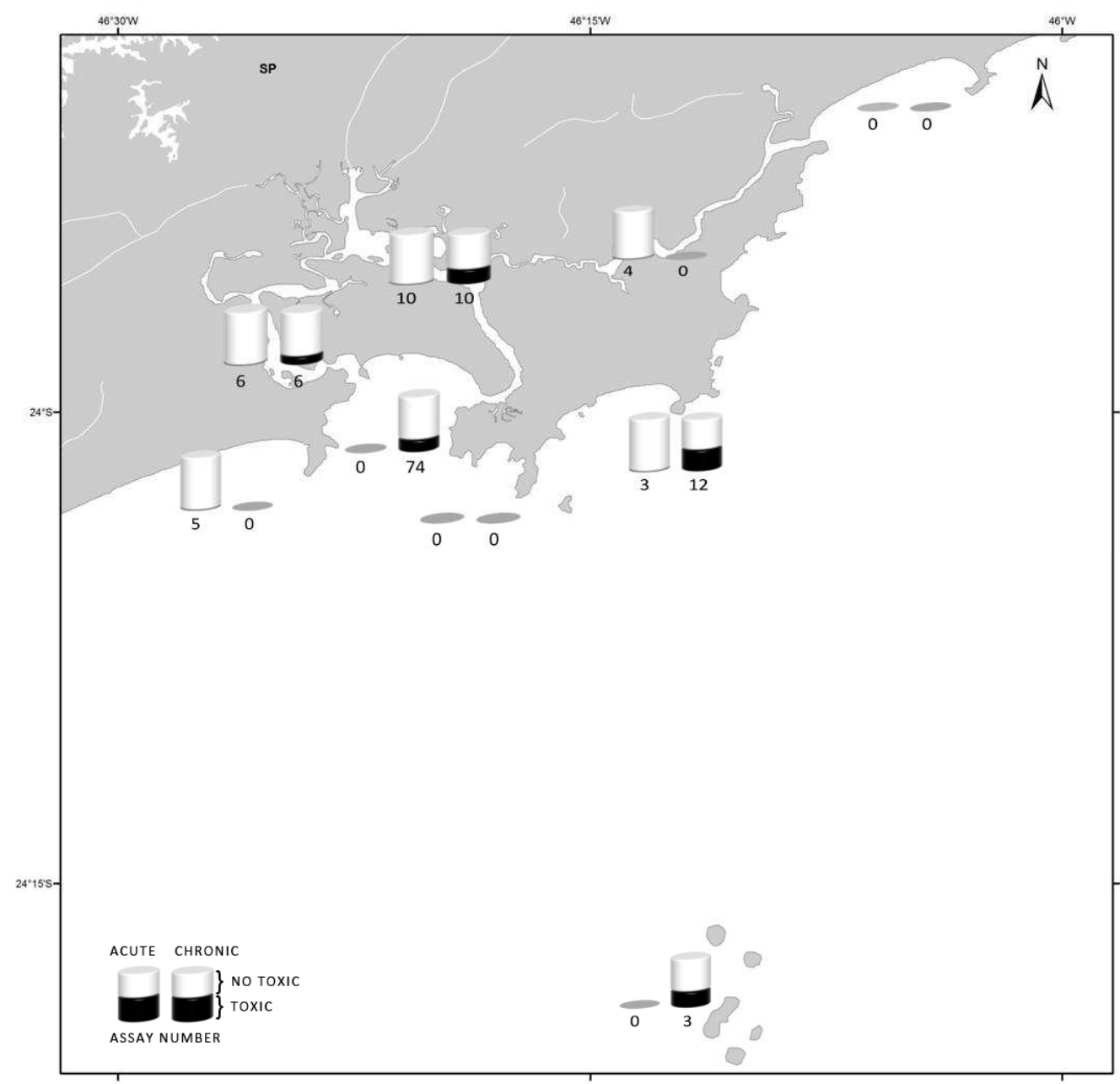

Fig. 2. Numbers of acute and chronic ecotoxicological assays performed in each area, as well as corresponding frequency (\%) of toxicity on samples from water column. 


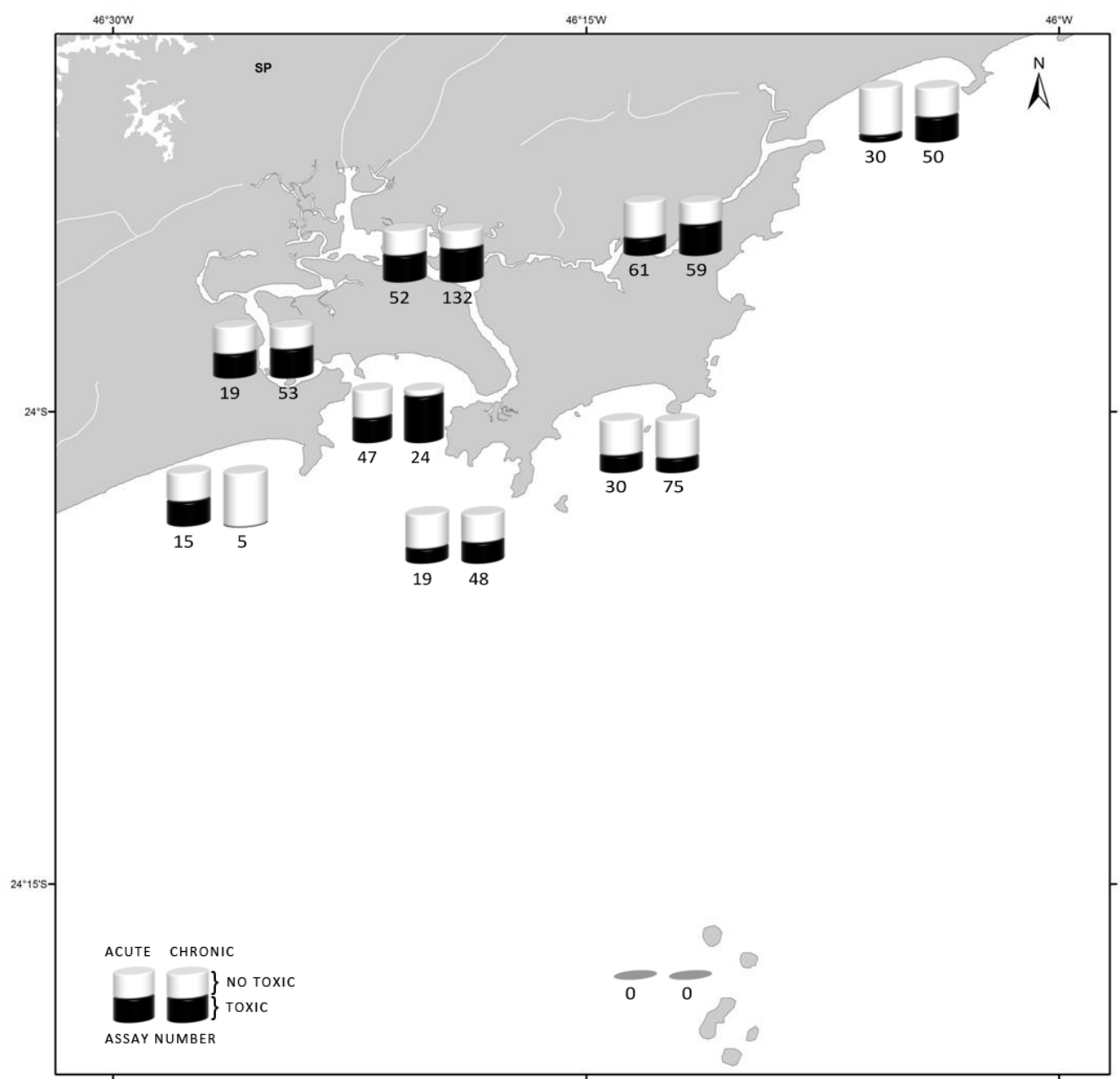

Fig. 3. Numbers of acute and chronic ecotoxicological assays performed in each area, as well as corresponding frequency (\%) of toxicity on samples from sediment and its fractions.

Comparing the results obtained from the acute and the chronic effect tests, it was found that the frequency of chronic toxicity was higher than the acute. That is probably a result of the greater sensitivity of the embryo-larval development stage of the sea urchin in relation to the survival of adult amphipods, and the interference caused by ammonia in the interstitial water. High levels of ammonia, frequently found in the interstitial water, may be the cause of effects in the embryo-larval development of $L$. variegatus, which is a contributing factor to the increase in the levels of toxicity found in the samples and has an impact on the results.

PROSPERI (2002) found a significant impact in the embryo-larval development of $L$ variegatus in concentration levels ranging from 0.08 to $0.15 \mathrm{mg} / \mathrm{L}$ of unionized ammonia and concluded that interstitial water samples from the estuaries of Santos may contain large amounts of nonionized ammonia, which, isolated, may lead to the overestimation of the toxicity of the samples.

The high frequency of acute toxicity in the Santos Channel is also found in Santos Bay around the submarine sewage outfall and in the dredged material disposal area; chronic effect tests similarly indicated greater toxicity in those places. However, lower toxicity frequencies for both acute and chronic assays were found around the beaches of Bertioga and Guarujá (Fig. 3).

The highest levels of metals in the Baixada Santista region were found on the inner side of the Santos Channel. According to HORTELLANI et al. (2008), elements such as $\mathrm{Hg}, \mathrm{Zn}$, and $\mathrm{Pb}$ were found in this area, in concentration levels above the PEL - 
Probable Effect Level (ENVIRONMENT CANADA, 2002). Large amounts of metals such as cadmium and chrome were also found by ABESSA et al. (2008) in the Santos Channel as far as the Piaçaguera Channel, with levels above the TEL - Threshold Effect Level (ENVIRONMENT CANADA, 2002), while Zn, Ni, $\mathrm{Pb}$ and $\mathrm{Hg}$ were found at levels above the PEL. Such limits are proposed by Canadian law for the conservation and protection of aquatic life, and have been the basis for the management of dredged material in Brazil (CONAMA 454 - 2012).

Organic contaminants such as aromatic cyclic hydrocarbons were also found in critical levels in the sediment from the Santos Channel. According to NISHIGIMA et al. (2001) and ABESSA et al. (2008), compounds such as anthracene, fluoranthene, pyrene, crisene, fluorene, acenaphthylene, acenaphthene and phenanthrene were found at concentrated levels above PEL on the inner side of the Santos Channel, near the Barnabé and Bagres islands, and in the Piaçaguera Channel.

The São Vicente and the Bertioga Channels have shown acute and chronic toxicity in intermediate frequency when compared to the other areas of the Baixada Santista. According to ABESSA et al. (2008), a few metals such as: cadmium, chrome and mercury, were detected at high concentration levels in the São Vicente Channel, as well as organic compounds such as anthracene, fluoranthene and chrysene above TEL.

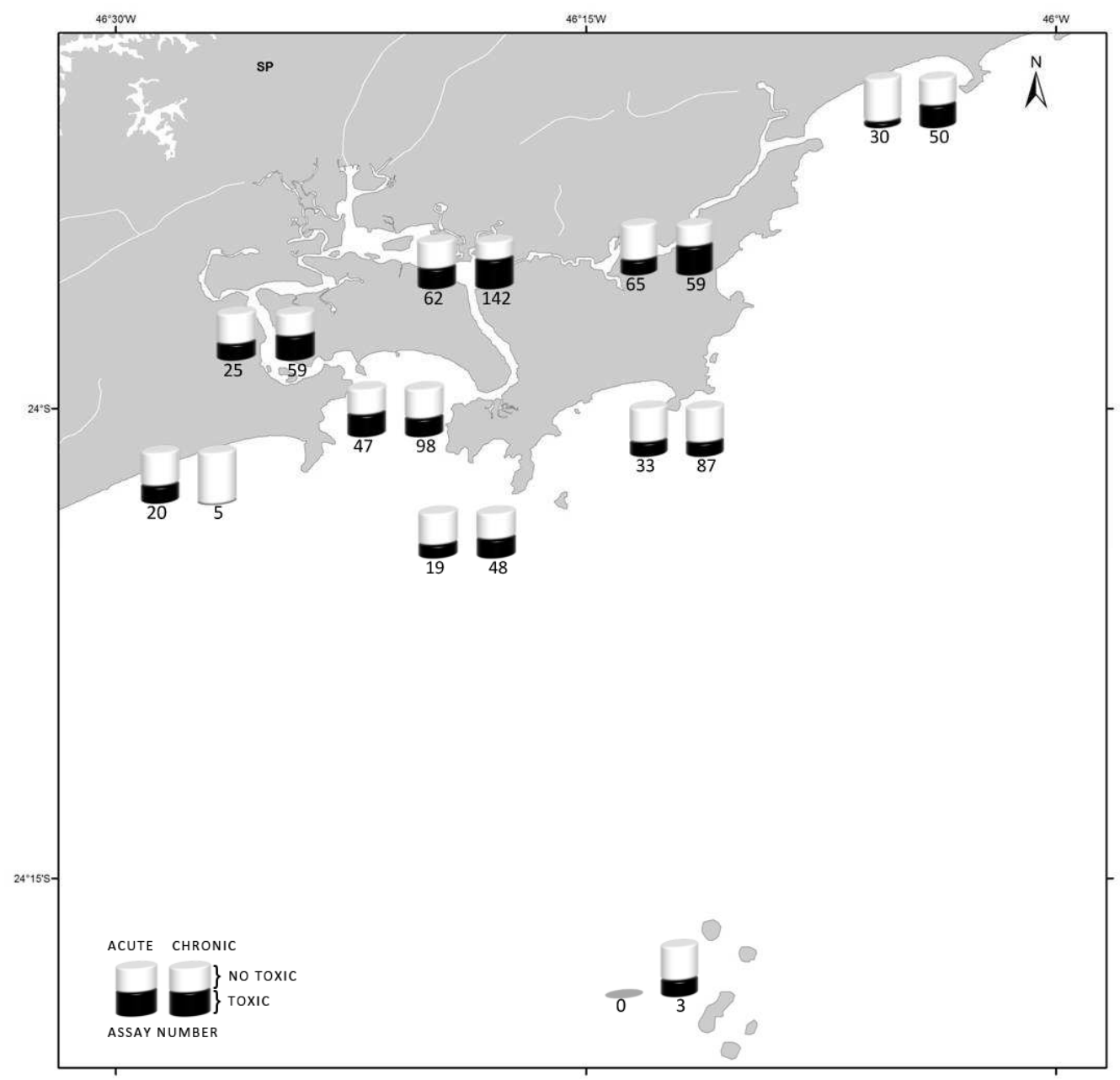

Fig. 4. Total number of acute and chronic ecotoxicological assays performed in each area, as well as the corresponding frequencies $(\%)$ of toxicity on samples from water column and sediment and its fractions. 
No contaminants such as metals and aromatic cyclic hydrocarbons were detected in the São Vicente Channel in levels as high as those in the Santos Channel. However, according to LAMPARELLI et al. (2001) drain waters contaminated by household sewage are constantly discharged into this area. This situation is confirmed by the presence of geochemical markers, such as linear alkylbenzene sulfonates, measured by MEDEIROS \& BÍCEGO (2004) and by the concentration levels of $E$. coli between 1,000 and 10,000 $\mathrm{nmp} / 100 \mathrm{~mL}$, which were the highest values found in the entire area of the estuary studied by SAMPAIO et al., 2008.

Although the frequency of toxicity in the Bertioga Channel was similar to that of the São Vicente Channel, metals and organic compounds were found by ZARONI (2006) in lower concentration levels than those obtained in the São Vicente Channel.

In the Bertioga Channel, only cadmium was found in concentration levels above TEL, as well as LABs (linear alkylbenzene sulfonates), which indicates the presence of household sewage and aromatic cyclic hydrocarbons in concentration levels similar to those found by MEDEIROS \& BÍCEGO (2004) in the Santos and São Vicente Bay and Channel. LAMPARELLI et al. (2001) found levels of mercury between TEL and PEL in the sediment of the Bertioga Channel, next to the Santos Channel.

At Praia Grande, Guarujá and on the beaches of Bertioga, the frequency of acute toxicity in the sediment was the lowest, although the number of samples tested in Praia Grande was much smaller than that of those tested in Guarujá and Bertioga. According to CETESB (2008), sediment contamination in Praia Grande and Guarujá reflects the discharges of submarine outfalls due to the flow of organic matter, contaminants and nutrients. The sediment in Praia Grande, however, does not show any accumulation of contaminants, while the study found dissolved copper and iron, total chrome and nickel in Guarujá, which indicates deposit in the sediments, though not related to the outfall.

In Bertioga, although there is no submarine outfall, some sites monitored by CETESB indicate a deposit of organic matter, fecal matter, and contaminants such as mercury, arsenic and others, which evidences the need for the application of measures to control the polluting sources in the area, in view of the fact that many nautical activities occur in that region.

These results suggest that the sediment is the great reservoir of the pollutants that may be made available by means of physical effects, such as bioturbation, diffusion or dredging (BELZUNCE et al., 2001 and CHAPMAN et al., 1987), in the case of the Santos Channel and dredged material disposal area (SOUSA, 2007 and ARGENTINO-SANTOS 2006).
Due to the high levels of contamination, dredging has not been allowed in some stretches of the Santos Channel - port. This activity has been permitted since 2006, provided that both the dredged material and the disposal area were monitored.

Levels of the metals $\mathrm{Ni}, \mathrm{Cr}, \mathrm{Cd}$ were found by ABESSA (2002) in concentrations above TEL; TORRES et al. (2007) also found $\mathrm{As}$ and $\mathrm{Hg}$ above the level I proposed by CONAMA 344/2004 in the dredged material disposal and dispersion area, located off the Guarujá coast, near Ponta do Monduba and Ilha da Moela.

Although the sampling number was very different across each of the individual areas, it was possible to determine that all of them had a certain degree of toxicity, as was also observed at Laje de Santos, which has Marine State Reservation status. However, the most critical condition is that of the Santos Channel region.

In addition to the acute and chronic toxicity assays reported above, recent studies have employed biomarker responses for assessing and monitoring the ecological status of Santos bay and the adjacent estuarine zones. ABESSA et al. (2005) assessed physiological and cellular responses of native and caged mussels from Santos bay. The authors observed that organisms transplanted from Ubatuba to Santos showed reduced stability of lysosomal membranes, indicating physiological stress.

KIRSCHBAUM et al. (2009) evaluated cytogenotoxic responses in erythrocytes from Centropomus parallelus juveniles collected in the São Vicente estuarine zone and observed micronucleus and nuclear abnormity frequencies 10 times greater than in specimens collected in Cananéia estuary, evidencing that the levels of pollution in the former estuary were high enough to induce genetic damage.

PEREIRA et al. $(2011,2012)$ performed the first biomonitoring along the São Paulo coast using biomarker responses of transplanted mussels Perna perna. Chemical analysis in whole tissues [polycyclic aromatic hydrocarbon (PAHs), linear alkyl benzenes (LABs), $\mathrm{Cd}, \mathrm{Cr}, \mathrm{Pb}$, and $\mathrm{Hg}$ ] were also performed with a view to assessing spatial and seasonal patterns of bioaccumulation and the link between biomarkers and contaminant body burden. In summary, these studies showed that biomarker responses and bioconcentration of contaminants exhibited more significant alterations in mussels transplanted to Itaipú (Santos Bay).

\section{Conclusion}

Ecotoxicological assays with samples from the Baixada Santista coastal zone have been carried out since the 1990s. In this study, it has been seen that these studies have not been undertaken systematically 
or continuously, but just occasionally. It should be remembered that companies that operate in the Baixada Santista region have undertaken monitoring studies, including ecotoxicological assays, in compliance with state and federal legislation - which has not been considered here.

Data from 852 ecotoxicological assays performed in the Baixada Santista region, from the 436 samples obtained, support the conclusion that this area presents varying degrees of toxicity across individual areas. Sediment from Santos Bay (near submarine sewage outfalls), Santos Channel, São Vicente Channel and Bertioga Channel are areas to have a greater potential negative impact on the biota than do the other areas, while the Bertioga Beaches and Guarujá areas have the lowest frequency of toxic effects.

Considering the Baixada Santista as a macro ecosystem that encompasses coastal environments such as estuaries and their mangrove forests, beaches, islands and conservation areas, one of the major industrial complexes and the largest port in Latin America and the most densely populated area of the coastal zone of São Paulo state, measures must be taken continuously to monitor both the release of pollutants that result from industrial, urban and port growth, and the associated physical and ecological changes.

Such monitoring would involve different lines of evidence such as ecotoxicological assays coupled with physical, chemical and ecological analysis. Integrated monitoring of the evolution of impacts on these ecosystems would be intended to generate knowledge, priority being given to more sensitive areas and to offering responses such as would ensure the improvement of the ecological status of this coastal zone

\section{REFERENCES}

ABESSA, D. M. S. SOUSA, E. C. P. M. Avances em Ecotoxicologia de sedimentos marinos em Brasil. IN: Toxicología y Química Ambiental. Contribuciones para um desarrollo sustentable. Jorge Herkovits (Ed.). Chapter 3: Contaminacion de suelos y sedimentos. 98100p. 2001.

ABESSA, D. M. S.; PEREIRA, C. D. S.; MACHADO, M. B. Toxicidade de água coletada na região do parque estadual marinho da Lage de Santos: Dados Preliminares. IN: IV Congresso Brasileiro de Pesquisas Ambientais e Saúde - IV CBPAS. Santos - SP. 2004.

ABESSA, D. M. S.; CARR, R. S.; RACHID, B. R. F; SOUSA, E. C. P. M.; HORTELANI, M. A.; SARKIS, J. E. Influence of a Brazilian sewage outfall on the toxicity and contamination of adjacent sediment. Mar. Pollut. Bull., (50):875-855. 2005

ABESSA, D. M. S.; ZARONI, L. P.; SOUSA, E. C. P. M.; GASPARRO, M. R.; PEREIRA, C. D. S.; RACHID, B.
R. F.; DEPLEDGE, M.; KING, R. S. Physiological and cellular responses in two populations of the mussel Perna perna collected at different sites from the Coast of São Paulo, Brazil. Braz. Arch. Biol. Technol., 48(2):217-225. 2005.

ABESSA, D. M. S.; SOUSA, E. C. P. M.; PEREIRA, C. D. S.; BAINY, A. C. D. Toxicidade de sedimentos marinhos e estuarinos de algumas localidades dos litorais de SP, RS e SC. IN: V Congresso Brasileiro de Pesquisas Ambientais e Saúde - V CBPAS. 2005.

ABESSA, D. M. S.; CARR, R. S.; SOUSA, E. C. P. M.; RACHID, B. R. F.; ZARONI, L. P.; GASPARRO, M. R.; PINTO, Y. A.; BICEGO, M. C.; HORTELLANI, M. A.; SARKIS, J. E. S.; MUNIZ, P. Integrative ecotoxicological assessment of contaminated sediments in a complex tropical estuarine system. $I N$ : Mar. Pollut.: New Research. Tobias N. Hofer (Ed.). Chapter 4. Nova Science Publishers Inc. ISBN: 978-160456-242-2. 2008

AMERICAN SOCIETY FOR TESTING AND MATERIALS - ASTM. Standard guide for conducting static acute toxicity tests starting with embryos of four species of saltwater bivalve mollusks. $I N$ : Annual Book of ASTM. Standards Philadelphia. E 724-89. Section 11, vol.11.04. 1992

ASSOCIAÇÃO BRASILEIRA DE NORMAS TÉCNICAS. ABNT NBR 15350. Ecotoxicologia aquática toxicidade crônica de curta duração - método de ensaio com ouriço do mar (Echinodermata: Echinoidea). Rio de Janeiro, 17p. 2006

ASSOCIAÇÃO BRASILEIRA DE NORMAS TÉCNICAS. ABNT NBR 15411. Ecotoxicologia aquática determinação do efeito inibitório de amostras de água sobre a emissão de luz de Vibrio fischeri (ensaio de bactéria luminescente). Rio de Janeiro. 2007.

ASSOCIAÇ̃̃O BRASILEIRA DE NORMAS TÉCNICAS. ABNT NBR 15638. Qualidade de água determinação da toxicidade aguda de sedimentos marinhos ou estuarinos com anfípodos. Rio de Janeiro. 19p. 2008.

BELZUNCE, M. J.; SOLAUN, O.; FRANCO, J.; VALENCIA, V.; BORJA, A. Accumulation of organic matter, heavy metals and organic compounds in surface sediments along the Nervión Estuary (North Spain). Mar. Pollut. Bull., 42(12):1407-1411. 2001

BORGES, R. P; FIORI, E. S. SANTOS, J. P. A.; ZARONI, L. P.; GIORDANO, F.; KODAMA, L. K.; MOYA, G. C.; ROSSO, S.; RIBEIRO, R. B. Zoobenthos of the Santos estuarine system. IN: Perspectives on Integrative Coastal Zone Management in South America. Neves, R.; Baretta, J. W.; Matheus, M. IST Press, Lisboa. 604p. 2008. 2008.

BRASIL CONAMA Resolução 454- Conselho Nacional do Meio ambiente - Estabelece diretrizes gerais e os procedimentos referenciais para o gerenciamento do material a ser dragado em águas sob jurisdição nacional. Diário Oficial (República Federativa do Brasil). Brasília 01 de novembro de 2012.

BRASIL CONAMA Resolução 344- Conselho Nacional do Meio Ambiente - Estabelece diretrizes gerais e os procedimentos mínimos para avaliação do material a ser dragado em águas jurisdicionais brasileiras, e dá outras providências. Diário Oficial (República Federativa do Brasil). Brasília 25 de março de 2004. 
BRASIL CONAMA Resolução 357- Conselho Nacional do Meio Ambiente - Dispõe sobre a classificação dos corpos de água e diretrizes ambientais para seu enquadramento, bem como estabelece as condições e padrões de lançamento de efluentes, e dá outras providências. Diário Oficial (República Federativa do Brasil) Brasília 17 de março de 2005

CATHARINO, M. G. M.; VASCONCELLOS, M. B. A.; SOUSA, E. C. P. M.; MOREIRA, E. G.; PEREIRA, C. D. S. Biomonitoring of $\mathrm{Hg}, \mathrm{Cd}, \mathrm{Pb}$ and other elements in coastal regions of São Paulo State, Brazil, using the transplanted mussel Perna perna (Linnaeus, 1758). Journal of Radioanalytical and Nuclear Chemistry (Print), v. 278, p. 547-551, 2008

CESAR, A.; PEREIRA, C. D. S.; SANTOS, A. R.; ABESSA D. M. S.; FERNÁNDEZ, N.; CHOUERI, R. B.; DELVALLS, T. A. Ecotoxicological assessment of sediments from the Santos and São Vicente estuarine system - Brazil. Braz J. Oceanogr., 54(1):55-63. 2006.

COMPANHIA DE TECNOLOGIA DE SANEAMENTO AMBIENTAL - CETESB. Água do mar - Teste de toxicidade crônica de curta duração com Lytechinus variegatus, Lamarck, 1816 (Echinodermata: Echinoidea). Norma Técnica L5.250. São Paulo, CETESB, 20p. 1992

COMPANHIA DE TECNOLOGIA DE SANEAMENTO AMBIENTAL - CETESB. Qualidade das aguas litorâneas do Estado de São Paulo. Balneabilidade das praias 2004. São Paulo: CD ROM (183p.): il. Série Relatórios/Secretaria de Estado do Meio Ambiente. CETESB, 2005. ISSN 0103-4103.

COMPANHIA DE TECNOLOGIA DE SANEAMENTO AMBIENTAL - CETESB. Relatório de qualidade de águas litorâneas do Estado de São Paulo: Balneabilidade das Praias 2005. São Paulo: CD ROM (365p.): il. Série Relatórios/Secretaria de Estado do Meio Ambiente. CETESB, 2006. ISSN 0103-4103.

COMPANHIA DE TECNOLOGIA DE SANEAMENTO AMBIENTAL - CETESB. Relatório de qualidade de águas litorâneas do Estado de São Paulo: Balneabilidade das Praias 2006. São Paulo: CD ROM (365p.): il. Série Relatórios/Secretaria de Estado do Meio Ambiente. CETESB, 2007. ISSN 0103-4103.

COMPANHIA DE TECNOLOGIA DE SANEAMENTO AMBIENTAL - CETESB. Relatório de qualidade de águas litorâneas do Estado de São Paulo 2008. São Paulo: CD ROM (330p.): il. Série Relatórios/Secretaria de Estado do Meio Ambiente. CETESB, 2009. ISSN 0103-4103.

CHAPMAN, P. The sediment quality triad approach to determining pollution- induced degradation. The Science of the Total Environment, (97/98):815-825. 1990.

CHAPMAN, P. M.; DEXTER, R.N.; LONG, E.R. Synoptic measures of sediment contamination, toxicity and infaunal community composition (the Sediment Quality Triad) in San Francisco Bay. Mar. Ecol. Progr. Ser., 37:75-96. 1987.

ENVIRONMENT CANADA. Canadian Sediment Quality Guidelines for the Protection of Aquatic Life Canadian Council of Ministers of the Environment. Update 2002.

U. S. ENVIRONMENTAL PROTECTION AGENCY USEPA. Short-term methods for estimating the chronic toxicity of effluents and receiving water to marine and estuarine organisms. EPA-600/4-87-028. Cincinati, Ohio. 1988

GEFFARD, O.; GEFFARD, A.; HIS, E.; BUDZINSKI, $\mathrm{H}$. Assessment of the bioavailability and toxicity of sediment-associated polycyclic aromatic hydrocarbons and heavy metals applied to Crassostrea gigas embryos and larvae. Mar. Pollut. Bull., (46):481-490. 2003.

GIANESELLA S. M. F.; SALADANHA-CORREA, F. M. P.; SOUSA, E. C. P. M.; GASPARRO, M. R. Ecological status of the Santos estuary water column. IN: Perspectives on Integrated Coastal Zone Management in South America. Neves, R. Baretta, J. W.; Matheus, M. IST Press, Lisboa. 604p. 2008.

HORTELLANI, M. A.; SARKIS, J. E. S.; ABESSA, D. M. S.; SOUSA, E. C. P. M. Avaliação da contaminação por elementos metálicos dos sedimentos do estuário Santos São Vicente. Quim. Nova, 31(1):10-19. 2008.

KIRSCHBAUM, A.; SERIANI, R.; PEREIRA, C. D. S.; ASSUNÇÃO, A.; ABESSA, D. M. S.; ROTUNDO, M. M.; RANZANI-PAIVA, M. J. T. Cytogenotoxicity biomarkers in fat snook Centropomus parallelus from Cananéia and São Vicente estuaries, SP, Brazil. Braz. J. Genet., 32(1):151-154. 2009.

LAMPARELLI, M. L.; COSTA, M. P.; PRÓSPERI, V. A.; BEVILACQUA, J. E.; ARAUJO, R. P. A.; EYSINK, G. G. L.; POMPEIA, S. Sistema Estuarino de Santos e São Vicente. Relatório Técnico. CETESB. São Paulo, 178p. 2001.

LINDEBOOM, H. The coastal zone: An ecosystem under pressure. IN: Oceans 2020: Science, Trends, and the Challenge of Sustainability. FIELD, J. G.; HEMPEL, G.; SUMMERHAYES, C. (Eds.). Island Press, Washington. pp.49-84. 2002.

LOTUFO, G. R.; ABESSA, D. M. S. Testes de toxicidade com sediment total e água intersticial estuarinos utilizando copépodos bentônicos. IN: Métodos em Ecotoxicologia Marinha: Aplicações no Brasil. NASCIMENTO, I. A.; SOUSA, E. C. P. M.; NIPPER, M. (Eds.). Editora Artes Gráficas e Indústria Ltda. São Paulo, 262p. Cap.13:151-162. 2002.

MEDEIROS, P. M.; BÍCEGO, M. C. Investigation of natual and antropogenic hydrocarbon inputs in sediments using geochemical marker. I. Santos, SP - Brazil. Mar. Pollut. Bull., 49:761-769. 2004.

MEDEIROS, P. O.; MARTINS, G. L. C.; LAPORTA, P. R.; SANTOS, A. R.; CESAR, A. CORTEZ, F. S. Avaliação comparativa das praias do Guarujá (Tombo, Enseada, Perequê, e Iporanga), através de testes de toxicidade com ouriço do mar (Lythechinus variegatus). Rvta Ceciliana, 1(2):141-146. 2009.

MELO, S. L. R.; NIPPER, M. Sediment toxicity tests using the burrowing amphipod Tiburonella viscana (Amphipoda: Platyischnopidae). Ecotoxicol. Environ. Safety, 66(2007):412-420. 2007.

NEVES, R.; BARETTA, J. W.; MATHEUS, M. (Eds.). Perspectives on Integrated Coastal Zone Management in South America. IST Press, Lisboa. 604p. 2008.

NISHIGIMA, F. N.; WEBER, R. R.; BICEGO, M. C. Aliphatic and aromatic hydrocarbons in sediments of Santos and Cananéia, SP, Brazil. Mar. Pollut. Bull., 42(11):1064-1072. 2001. 
PEREIRA, C. S. D.; ROTUNDO, M. M.; IANUZZI, A.; FERRAZ, N. L.; SANTOS, A. R. Avaliação da toxicidade das águas superficiais e de fundo de uma área próxima à desembocadura do Estuário de Santos. IN: Congresso Brasileiro de Pesquisas Ambientais e da Saúde, 4. IV CBPAS. 2004.

PEREIRA, C. D. S., MARTÍN-DÍAZ, M. L., ZANETTE, J., CESAR, A., CHOUERI, R.B., ABESSA, D.M.S., CATHARINO, M. G. M., VASCONCELLOS, M. B. A., BAINY, A. C. D., SOUSA, E. C. P. M., DEL VALLS, T. A. Integrated biomarker responses as environmenta status descriptors of a coastal zone (São Paulo, Brazil). Ecotoxicology and Environmental Safety 74, 1257-1264. 2011

PEREIRA, C. D. S.; MARTÍN-DÍAZ, M. L.; CATHARINO, M. G. M.; CESAR, A.; CHOUERI, R. B.; TANIGUCHI, S.; ABESSA, D. M. S.; BÍCEGO, M. C.; VASCONCELLOS, M. B. A.; BAINY, A. C. D.; SOUSA, E. C. P. M.; DELVALLS, T. A. Chronic contamination assessment integrating biomarkers' responses in transplanted mussels - A seasonal monitoring. Environ. Toxicol., 27:257-267. 2012.

POWER, E.; CHAPMAN, P. Assessing sediment quality. IN: BURTON JR, G. A. (Ed.). Sediment Toxicity Assessment. Chelsea, Lewis Publishers, Inc., 1-18. 1995.

PRÓSPERI, V. A., EYSINK, G. G. J.; SAITO, L. M Avaliação do grau de contaminação do sedimento ao longo do canal de navegação do Porto de Santos. Relatório Técnico. CETESB. São Paulo, 33p. 1998.

POZO H. V.; DAVANSO, M. B.; MOREIRA, L. B. ABESSA, D. M. S. Toxicidade aguda de sedimentos na área de influência de uma marina no canal da Bertioga. IN: Simpósio Brasileiro de Oceanografia, 5. 2011.

PUSCEDDU, F. H.; ALEGRE, G. F.; PEREIRA, C. D. S ; CESAR, A. Avaliação da toxicidade do sedimento do Complexo Estuarino de Santos empregando ouriços-domar Lytechinus variegatus (Echinoidea: Echinodermata). J Braz. Soc. Ecotoxicol., 2(3):237-242. 2007.

RAND, G.; WELLS, P.; MCCARTY, L. Introduction to aquatic toxicology. IN: Fundamentals of Aquatic Toxicology. Effects Environmental, Fate and Risk Assessment. Rand, G. M. (Ed). $2^{\text {nd }}$ Edition. 3-67. 1995.

ROSEN, G.; RIVERA- DUARTE, I.; KEAR-PADILLA, L.; CHADWICK, D. B. Use of laboratory toxicity tests with bivalve and echinoderm embryos to evaluate the bioavailability of copper in San Diego Bay, California, USA. Environ. Toxicol. Chem., 24(2):415422. 2005

SAMPAIO, A. F. P.; FERREIRA, J. M. S. Socio-economic issues in the Santos estuary. IN: Perspectives on Integrated Coastal Zone Management in South America. Neves, R. Baretta, J. W.; Matheus, M. (Eds.) IST Press, Lisboa. 604p. 205-218. 2008.

SOUSA, E. C. P. M. Métodos em ecotoxicologia marinha $I N$ : NASCIMENTO, I.; SOUSA, E. C. P. M.; NIPPER, M (Eds.) Métodos em Ecotoxicologia Marinha: Aplicações no Brasil. Editora Artes Gráficas e Indústria Ltda, São Paulo. 262p. Cap. 1:9-14. 2002.

SOUSA, E. C. P. M.; ABESSA, D. M. S.; ACHID, B. R. F.; GASPARRO, M. R. Ecotoxicological assessment of sediments from the port of Santos and disposal sites of dredged material. Braz. J oceanogr., 55(2):75-81. 2007

SOUSA, E. C. P. M.; CESAR, A.; GASPARRO, M. R.; ARGENTINO-SANTOS, R. C.; ZARONI, L. P.; PEREIRA, C. D. S.; BERGMANN FILHO, T. U.; OLIVEIRA, L. F. J. Sediment quality of the Santos estuarine system. IN: Perspectives on Integrated Coastal Zone Management in South America. Neves, R. Baretta, J. W.; Matheus, M. (Eds.). IST Press, Lisboa. 604p. 195-204. 2008.

TORRES, J. R.; ABESSA, D. M. S.; SANTOS, F. C.; MARANHÃO, L. A.; DAVANSO, M. B.; NASCIMENTO, M. R. L.; MOZETO, A. Effects of dredging operations on sediment quality: contaminant mobilization in dredged sediments from the Porto of Santos, SP, Brazil. J Soils Sediment, (9):420-432. 2009.

ZARONI, L. P; ABESSA D. M. S. LOTUFO, G. R; SOUSA, E. C. P. M.; PINTO, Y. A. Toxicity testing with embryos of marine mussels: Protocol standardization for Perna perna (Linneus, 1758). Bull. Environ. Contam. Toxicol., (74):793-800. 2005.

\section{Sources of Unpublished Material}

ABESSA, D. M. S. Testes de toxicidade de sedimentos da região de Santos - SP - Brasil $\left(24^{\circ} \mathrm{S}, 46^{\circ} \mathrm{W}\right)$, utilizando o anfípodo escavador Tiburonella viscana (Crustacea Platyischnopidae) Thomas \& Barnard (1983). Universidade de São Paulo. Instituto Oceanográfico. Dissertação de Mestrado. 97p. 1996.

ABESSA, D. M. S. Avaliação da qualidade de sedimentos do Sistema Estuarino de Santos, SP, Brasil. Universidade de São Paulo. Instituto Oceanográfico. Tese de Doutorado. 290p + Anexos. 2002.

ARGENTINO-SANTOS, R. C. Avaliação ecotoxicológica do sedimento do local de disposição do material dragado do Porto de Santos e da área de influência direta. Universidade de São Paulo. Instituto Oceanográfico. Dissertação de Mestrado. 124p. 2006.

CORTEZ, F. S. Avaliação ecotoxicológica do fármaco triclosan para invertebrados marinhos. 2010. Dissertação de Mestrado. IPEN. São Paulo. 2010.

MELO, S. L. R. Testes de toxicidade com sedimentos marinhos: adequação da metodologia para o anfípodo escavador Tiburonella viscana. Dissertação de Mestrado. Universidade de São Paulo. Escola de Engenharia de São Carlos. 172p. 1993

MOREIRA, L. B. Avaliação da toxicidade dos sedimentos e macrofauna bentônica em áreas portuárias: Porto do Mucuripe e Terminal Portuário do Pecém (CE); e Porto de Santos (SP). Dissertação de Mestrado. Universidade Federal do Ceará. Instituto de Ciências do Mar. 128p + anexos. 2009

PRÓSPERI, V. A. Comparação de métodos ecotoxicológicos na avaliação de sedimentos marinhos e estuarinos. Tese de Doutorado. Universidade de São Paulo. Escola de Engenharia de São Carlos. 100p. 2002.

RACHID, B. R. F. Ecotoxicidade de efluentes sanitários urbanos lançados ao mar através de emissários submarinos. Universidade de São Paulo. Instituto Oceanográfico. Dissertação de Mestrado. 106p. 1996. 
TORRES, R. J. Efeitos da dragagem sobre a qualidade de sedimentos contaminados do Canal do Porto de Santos: biodisponibilidade e toxicidade de metais e compostos orgânicos persistentes. Tese de Doutorado. Universidade Federal de São Carlos. Centro de Ciências Exatas e de Tecnologia. 157p + anexos. 2007.

ZARONI, L. P. Avaliação da qualidade dos sedimentos marinhos e estuarinos no Município de Bertioga - SP. Universidade de São Paulo. Instituto Oceanográfico. Tese de Doutorado. 193p. 2006.

(Manuscript received 25 April 2013; revised 16 April 2014; accepted 22 April 2014) 